\title{
The Aesthetic Features and Significance of the Veritism in Garland's Short Stories - A Study on Main-Travelled Roads
}

\author{
Neng-wei Fan \\ Correspondence: Neng-wei Fan, School of Foreign Languages, Yancheng Normal University, Yancheng, China. \\ Received: December 24, 2019 \\ Accepted: February 5, 2020 \\ Online Published: February 11, 2020 \\ doi:10.5430/elr.v9n1p20 \\ URL: https://doi.org/10.5430/elr.v9n1p20
}

\begin{abstract}
Hamlin Garland, an influential American writer, puts forward his literary theory-Veritism. His collection of short stories-Main-Travelled Roads insists on describing the real situation of Midwest and West rural areas by using "Veritism", as well as expresses the great humanistic concern and deep thinking about the changes that had taken place between urban and rural areas. By analyzing the figures and plots of Main-Travelled Roads, this paper will reveal humanism and classical sensibility, happy endings, and aesthetic value in it, and let readers understand the theme of the short stories thoroughly, and appreciate the Veritism comprehensively.
\end{abstract}

Keywords: humanism and classical sensibility, happy endings, aesthetic value, Veritism

\section{Introduction}

Hamlin Garland (1860-1940) is a famous native writer of America in the end of 19th century and in the beginning of 20th century. As a novelist with great consciousness and strong local characteristics, he made tremendous contributions to the formation of American national literature owing to his artistic thoughts and literary practice. In order to objectively reflect the reality and reveal the truth of life, Garland pioneered his special literary theory -"Veritism".

Veritism is first put forward in his literature manifesto-Crumbing Idols, in which Garland points out that the essence of veritism is to "write of those things of which you know most, and for which you care most" (Garland, 1894, p.35). It "deals with life face to face, and swiftly and surely and always from the individual artist's standpoint" (Garland, 1894, p.94). It is "a combination of vivid description of details in realism and the preference to personal observation in impressionism" (Luo, 2006, p.17). The veritist is "occupied in stating his sincere convictions, believing that only in that way is the cause of truth advanced" (Garland, 1894, p.21). He aims at "the truthful statement of an individual impression corrected by reference to the fact" (Twadell, 1964, p. 412). In his short stories, Garland, by his veritism, emancipated the American Midwest and West and the American farmer particularly from the romanticized conception. His short stories had obvious local color, and depicted the nature disaster, unfair social system, backward thinking and painful life which western immigrants suffered in the Westward Movement, and reflected the miserable world which they suffered, and the extreme contribution, sacrifice spirits and growing process of the young generation in characters, talent and morality.

With deep appreciation for his parents and a great affection for the land where he was born, Hamlin Garland called himself "a son of the middle border". In order to let Americans understand the adventure and hardship in the wild west and to be conscious of the heavy price the generation of western farmers from his father's generation paid in the process of urban and rural modernization, Garland created his first collection of short stories Main-Travelled Roads after careful observation and profound reflection on life.

\section{Literature Review}

Main-Travelled Roads first appeared in 1891 with the subtitle "Six Mississippi Valley Stories". One of these six, "The Return of the Private", had first appeared in the Arena; and "Under the Lion's Paw", "Among the Corn Rows", and "Mrs. Ripley's Trip" had already been published in Harper's Weekly. "A Branch Road" and "Up the Coule" saw first publication in the 1891 edition. Later, Garland added the new stories: "The Creamery Man”, "A Day's Pleasure”, "Uncle Ethan Ripley”, “God's Ravens", and “A Good Fellow's Wife”. And finally in 1930 Garland added "Martha's Fireplace". 
Main-Travelled Roads was considered an important publication in nineteenth century American literature, and it was "a powerful and evocative treatment of Western farm life" (McCullough, 1978, p. 40). At least, it represented "a protest against the romantic portrayal of the Middle West" (Ahnebrink, 1961, p. 137). Its poignant portrayal of man's struggles against the forces of nature and social injustices led Howells to observe that:

If any one is still at a loss to account for that uprising of farmers in the West which is the translation of the Peasant's War into modern and republican terms, let him read Main-Travelled Roads, and he will begin to understand, unless, indeed, Mr. Garland is painting the exceptional rather than the average. The stories are full of those gaunt, grim, sordid, pathetic, ferocious figures, whom our satirists find so easy to caricature as Hayseeds, and whose blind groping for fairer conditions is so grotesque to the newspapers and so menacing to the politicians. They feel that something is wrong, and they know that the wrong is not theirs. The type caught in Mr. Garland's book is not pretty; it is ugly and often ridiculous; but it is heart-breaking it is rude despair. (Howells, 1957, p. 38)

And, Donald Pizer (1954) pointed out that "all the stories conceived during this period present hardship, poverty, and lack of culture in the West" (p. 415). Even today It is best known for its strongly regional, unpretentious pictures of the brutalizing life on the farms and in the isolated communities of the monotonous prairie lands. Critics cite its value both as an innovative collection of realistic short fiction and as a social artifact that provides insight into rural American life and the reform movements of the time. However, some critics argued that Garland's depiction of the midlands was a complete fabrication, and his work left no trace of the realities of life, just the gruesomely ugly and trivial realities. Some critics flew at his head, railing at a "bird who would foul his own nest" (Garland, 1917, p. 41). Some Reviewers had criticized the didactic qualities of the book and its overwhelming emphasis on the grim aspects of farm life.

In fact, as a pioneer of Veritism and local color literature, Garland's work in the volume graphically describes the lives and surroundings of his characters. The vivid description of details and impressions under specific circumstances triggered readers' sense of sympathy and a state of shock. The aesthetic features and significance of the Veritism in Main-Travelled Roads are worth appreciating.

\section{Humanism and Classical Sensibility in Main-Travelled Roads}

Garland is always considered as an intellectual with humanism and classical sensibility. This kind of feeling is not only related to his character but also owing to his Veritism. He disagreed with naturalism's simple description of human desires and primitive impulse, and he advocated reflecting the "great glory" of life under specific circumstances.

Unrelenting physical toil and loneliness were the undertones of country life in Garland's short stories. People struggled in hopeless work under the harsh natural environment, in the unfair social and economic system. People despaired of the impoverished material life and poor mental-spiritual world. However, there was still an underlying optimism that could be found in Garland's mind about the countryside. Had a cramped and strait life under all sorts of forces in rural areas, people never completely lost their confidence and hope for life and holding a trace of kindness and love in their hearts in his short stories. In The Return of A Private, the old window, Grey, a warm-hearted neighbor, invited Mrs. Smith's family for lunch and attentively comforted her when she was in the loneliest and most desperate time. In Under the Lion's Paw, when Haskins' family suffered from cold and hunger, with nowhere to go in the snowstorm night, Kangsier couple, who not only helped them survive through the present cold and hunger but also helped them build a new house later. In A Day's Pleasure and God's Ravens, when the protagonist was in trouble, there were always warm and kind strangers or neighbors giving them a warm hand in time. There are many such details in Garland's stories, and every time as we read, we feel warm and moving, which becomes the highlights in a hard and desperate life.

Although born at the time of great changes in American society, Garland was an intellectual who respected the traditional culture, which was to some extent related to the influence of his early education from his family, especially from his mother. The pursuit of not only the perfection of his life but also the moral responsibility of his family and society made Garland tend to create such characters with both intelligence and virtue. For instance, Will and Howard in A Branch Road and Up the Coolly respectively bravely stood out to fight for their lovers in a dilemma after they came back home. Mrs. Ripley, the female protagonist in Mrs. Ripley's Trip, as a housewife, had a strong sense of moral responsibility. She never forgot to undertake the due responsibility for her family as she pursued personal value and happiness. These characters created by Garland were all outstanding figures emerging in the period of social changes, and their optimistic, kind and moral qualities were not only Garland's moral pursuit as an intellectual but also became a reflection of his understanding and appreciation of rural people. It was because of 
his humanism and classical sensibility that the desperate world under his pen became not so much intolerable, in which way he wanted to give people an emotional shock and comfort and to express his seeking for a better life.

\section{Happy Endings in Main-Travelled Roads}

Veritist "aims to hasten the age of beauty and peace, and he sighs for a lovelier life" (Garland, 1894, p.52). Actually, besides criticizing and exposing the real rural life, Veritism that Garland proposed wanted to make readers feel the hope of life. So, Most of Garland's stories end hopefully and some even happily in Main-Travelled Roads. "Happy ending" is a form of literary creation. "It is the expression of the cultural traditions of "upholding harmony and golden mean' in literary narration from the perspective of philosophy and aesthetics, the embodiment of the principle of justice and the expression of ethical belief from the aspect of ethics and morality, and also a carrier of social psychology of the recipient and the author himself in terms of social aesthetic psychology" (Li, 2013, p. 9). "Happy endings" are a distinct feature in the literary creation of Garland to show his faith and attitudes towards life and convey his evaluations of moral values. In Main-Travelled Roads, Garland spares none of his principal characters a bitter sense of failure, but most of them manage to overcome it.

In A Branch Road, the main character Will, when he came back after a long separation, found his former lover who had married and had a painful and miserable life. However, at the end of the story, he helped his lover escaped from the "cage" and ran towards a new happy life. In Up the Coolly, the two brothers put down their deep conflicts and reconciled at last. While in God's Ravens, Robert realized the plain and unsophisticated characters of these villagers after his illness, though he and his family felt upset for their failure to get used to the village lifestyle when they moved in from urban areas.

There are many other similar stories in Garland's collection, which filled with conflicts and hardships but always kept turns for a better or bright future. Therefore, Garland was denounced by critics for his insufficient criticism of life. However, we all know that in Garland's period American farmers witnessed urban and rural changes, suffered from the failure of western reclamation, stricken by numerous natural disasters and had a terrible living environment. If we put ourselves in the position of Garland, we will understand that such feature is just the reflection of the author to the present and the future, and also an introspection about how can the villagers go through the tough period in the country permeated with the atmosphere of decline and despair, and how can they regained the confidence and smoothly adapt to the transition of modernity.

Garland believes that "the realist or verities is an optimist, a dreamer" (Garland, 1894, p.52). Since the advancement of urbanization and the development of science and technology bring indifference and tense among human relationship, Garland, with an eye for discovery, perceives and records rural life, which is actually the reminiscence of the fading local civilization and also an affirmation to the excellent younger generation. Furthermore, with a bright ending, it not only presents rural life but also make much room for readers to imagine what the future should be like, which is the requirements of Veritism aesthetics-full of hope.

\section{Aesthetic value in Main-Travelled Roads}

Garland's stories reflect the daily life of people in the Midwest during the great turning point in American history. Trapped in the misery process of industrialization, suffered from the trouble of economic destitution, these people were left behind by the transformation of the United States from an agricultural country to an industrial country. Garland observed the villagers struggle on the land as a dual identity of farmer and a city people, under the guidance of Veritism, he truthfully and objectively recorded the joys and sorrows in their daily life, which is not only the expression of the authors' moral pursuit but also the manifestation of the spirit of times. Therefore, it is of necessity to re-examine both the spiritual realm and aesthetic values in Main-Travelled Roads

Hamlin Garland was a traditional intellectual with a strong sense of moral responsibility. He especially had a deep affection for the acquainted countryside where he once lived. Two consecutive returns back home deepened his understanding of rural life. Garland recorded the desolated and dilapidated countryside and the endless toil along with loneliness and helplessness of farmer, which is a manifestation of his deep humanistic awareness.

As an earnest and simple rural writer, Garland got creative ideas from a realistic environment, with the creative purpose of recording the real life of common people and sharing the truth of their own lives. For example, he got the inspiration of the story Mrs. Ripley's Trip when talking with his mother, who sent a letter to Garland after the publishing of the Main-Travelled Roads, which expressed how she astonished by the sincerity of stories. "It scares me to read some of your stories - they are so true" (Garland, 1917, 416). What's more, there was another woman wrote to Garland, "You are entirely right about the loneliness, the stagnation, the hardship. We are sick of lies. Give 
the world the truth" (Garland, 1917, 417). These two examples convincingly demonstrate the popularity of Garland's stories for his concern for ordinary people and truly and striking expression of the aspiration of ordinary people.

Garland's humanistic concern was also reflected in his thoughts and concerns about the fate of the new generation. Garland also created some new images of rural villagers who could be the role models of the new generation of rural people, became matured through struggles in life, for instance, in the story Among the Corn Rows, Rob who was born in a peasant family and fought for livelihood in the farm as well as his lover Julia, a girl who not only duly handled her career and dreams but also properly took the responsibility of taking care of her own family. Through narration and affirmation to these young people, Garland showed his reflection on the future of countrymen. What's more, Garland's showed his worries about the fate of the descendants in the countryside by revealing the real situation with Veritism techniques: Children, lacking inadequate care, rolled on the ground like toads in the noisy, dirty street, and filled with suffocating and irritable air and rude complaints of adults. Such a scene description contained the instant experience of impressionism, which combined Garland's subjective feeling with reality, showing the author's concerns about rural children's living conditions and futures development.

At the end of the 19th century and the beginning of the 20th century, the industrialization of the United States was in full swing, which not only profoundly changed the social life but also caused conflicts and changes in social values. The system of capital monopoly and exploitation formed by the emerging industrial civilization had a great impact on traditional agricultural production, and deprived the freedom and equality of peasants, and turned them into landless farmers living in growing poverty. Garland tactfully captured the subtle changes in that process and put them into his stories so that the complex contradiction between people's life and morality in rural-urban civilization can be reflected.

Usually, such contradiction was manifested by those returning home after a long separation. Take Will in A Branch Road and Howard in Up the Coolly as example, they all played the role of observers to the countryside, astonished and disappointed, their ideological ambivalence was also caused because of the huge gap between rural and urban development. These characters were the incarnation of Garland, being a local intellectual who wandered in urban and rural areas, enabled him to examine the surroundings objectively.

There were two forms of expressions of rural-urban contradiction under such narrative pattern: The first was the dissociation of individual identity, which was to say, vacillating between rural and urban lives. In the conversation with the villagers after Garland's return back home, people in the village expressed the longing for the outside world, and euphemistically showed their disliking for toil labor and the disgust to the place where they hoped to escape from. For example, in the story A Branch Road, Ed says that "they say you've made a pile of money out West, Bill. I'm glad of it. We fellers back here don't make anything. It's a dam tight squeeze" (Garland, 1899, 52). It revealed a complex mixture of admiration and misunderstanding of those who trapped in the village to people who had fled the countryside. While the second is the decline of rural values. The inevitable results of losing local civilization accounting for the progress of urbanization, a cruel shock of reality as well as the nostalgia brought deep anxiety and despair in people's mind.

Faced with the extinction of the idyllic picture of liberty, equality, and prosperity, exploitation and inequality in profit distribution, "free peasants who once regarded themselves as the mainstay of American society painfully and dejectedly realizing that their social status was rapidly compared with those in rising industrial cities in the eastern areas"(Luo, 2009, p. 76-77).The harsh weather, painstaking work, the incessant loneliness and boredom on the Midwest frontier were unbearable. As for the poor peasants' children in rural areas, they have virtually lost their citizenship and been excluded from the mainstream society because of their unavailability to a proper education, a secure life and shortage in any cultural and recreational activities, just the same as the children wandering around in the street without good cares depicted in the short stories. Through the depictions of the rural world in short stories, the mounting sense of disillusionment was emphasized. Under such atmosphere, the inevitable change of farmers' values from optimism to despair can be perceived.

\section{Conclusion}

The true reflection of American rural life and local characteristics in Garland's short stories opened a new chapter in American literature-American national literature, from which the ordinary life of ordinary characters began to become part of serious literature. Under the guidance of Veritism, Garland delineated the real scene of rural life in the United States, comply with impressionism's sense of the "moment-to-moment" atmosphere and similar with the sincere depiction of naturalism. Therefore, the stories and characters were lively and impressive. Life was cruel and hard, no matter to settle in the west or struggle for livelihood in urban areas. Through the records of the western reclamation of his father's generation, Garland showed their striving spirit as well as the American spirit forming in 
the process. It is embodied in the spirit of individualism in the aspects of self-consciousness, individual struggle, and individual value as well as the consciousness of pursuing the "American dream". Both men and women in his short stories had a strong spirit of individualism, such as, Howard who properly balanced his values and family responsibilities, and Julia, who boldly pursued personal happiness. Julia's escaping reflected the awakening of female's consciousness and her desire for freedom and equality. The elder generation's unsung courage to work in the face of hardship and the young generation's optimistic and unyielding struggle for themselves. Such spirit of ordinary people shown in their daily life was revealed by Garland in American literature with a vision of understanding and appreciation, becoming a part of rural life. In the United States at that time, these ordinary people were the rising and growing middle class, representing the backbone of the development of American society. Their temperament and spirit exactly reflected the rising national character and core values of the United States, which have been carried forward and transferred to the modernization process, even gathered in the history and culture of the whole country.

\section{Acknowledgements}

This research is Supported by Social Science Foundation Project of Jiangsu province, (NO.19WWB004) and the Philosophy and Social Sciences Research Foundation Project of Jiangsu Higher Education Institutions (NO. 2018SJA1511).

\section{References}

Ahnebrink, L. (1961). The Beginnings of Naturalism in American Fiction. New York: Russell \& Russell.

Garland, H. (1894). Crumbling Idols. Chicago: Stone and Kimball.

Garland, H. (1899). Main-travelled Roads. New York: Harper \& brothers.

Garland, H. (1917). A Son of the Middle Border. New York: Macmillan.

Howells, W. D. (1957). Prefaces to Contemporaries 1882-1920. Gainesville, Florida: Scholars' Facsimiles \& Reprints.

Li, Z. Q. (2013). The Cultural Implications of a Happy Ending. Journal of Yangtze University (Social Sciences Edition), 12, 9-12.

Luo, X. Y. (2006). Early Exploration in American Literature: Garland's Main-Travelled Roads and Veritism Experiment. Journal of Si Chuan International Studies University, 6, 14-18.

Luo, X. Y. (2009). American Western Literature. Hefei: Anhui education press.

McCullough, J. B. (1978). Hamlin Garland. Boston: Twayne Publisher, Inc.

Pizer, D. (1954). Hamlin Garland in the Standard. American Literature, 26(3), 401-415. https://doi.org/10.2307/2921694

Twadell, S. J. (1964). Dictionary of World Literature: Criticism, Forms, Technique. New York: Taylor \& Francis. 